\title{
КЕРУВАННЯ ЕЛЕКТРОПОЇЗДАМИ МЕТРОПОЛІТЕНУ НА ОСНОВІ НЕЙРОННИХ МЕРЕЖ АДАПТИВНОЇ РЕЗОНАНСНОЇ ТЕОРІЇ
}

\author{
Частина 2. Розробка методу оптимізації руху поӥза метрополітену \\ на основі дискретної нейронної мережсі АРТ-1
}

\author{
Представив д-р техн. наук, професор М.М. Бабаєв
}

\begin{abstract}
Вступ, аналіз публікацій, формулювання задачі дослідження. При експлуатації електропоїздів залежно від зовнішніх умов і стану електропривода можуть суттєво змінюватися режими роботи тягових двигунів. Оперативна оцінка цих процесів і наступне коректування режимів роботи електропривода, навіть при наявності відповідної інформації, вимагають часу для їхньої обробки й високої кваліфікації машиніста, що не завжди можливо в умовах руху
\end{abstract} електропоїзда. Мінімізувати енергетичні витрати та підвищити безпеку руху поїздів можливо шляхом впровадження нейронних мереж в процес керування усіма видами рухомого складу залізничного транспорту $[1,2,5]$. Можливим варіантом вирішення цієї задачі $€$ використання асоціативної пам'яті на основі дискретної нейронної мережі АРТ-1 [3]. Подальшим продовженням цієї роботи $\epsilon$ реалізація методів оптимального керування електропоїздами метрополітену на основі нейронних мереж адаптивної резонансної теорії.

Мета дослідження. Оптимізація методів оптимального керування електропоїздами метрополітену.

Основна частина. На основі дискретної нейронної мережі АРТ-1 пропонується асоціативна пам'ять, зображена на рис. 1, що складається із двох модулів, кожний 3 яких $є$ нейронною мережею АРТ-1.

Модуль 1 використовується для запам'ятовування кодів перегонів, а модуль 2 - для зберігання законів руху електропоїзда по перегону, наприклад, у вигляді графіків.

Машиніст за допомогою блока керування задає код перегону, який подається на вхідні нейрони модуля 1. Цей код визначає нейрон-переможець $Y_{J}$ у шарі розпізнавальних елементів вихідний сигнал якого через нейрон $\mathrm{A}_{\mathrm{J}}$ асоиіативного $A$-шару нейронів ( при наявності сигналу визначення асоціації на виході блока керування) надходить на вхід нейрона $\mathrm{Y}_{\mathrm{J}}$ другого модуля асоціативної пам'яті.

У пам'яті кожного Ү-нейрона зберігається траєкторія руху електропоїзда по відповідному перегону. За вхідним сигналом 3 виходу модуля 1 будь-який $\mathrm{Y}$ нейрон модуля 2 через нейрони шарів $Z$ i $S$ видає на екран монітора машиніста зображення траєкторії руху состава по перегону. На цьому ж екрані відображається не тільки рекомендована (оптимальна) траєкторія руху, але й поточна траєкторія руху. Наявність цих двох траєкторій дозволяє машиністові підтримувати енергозберігаючий режим руху електропоїзда. 


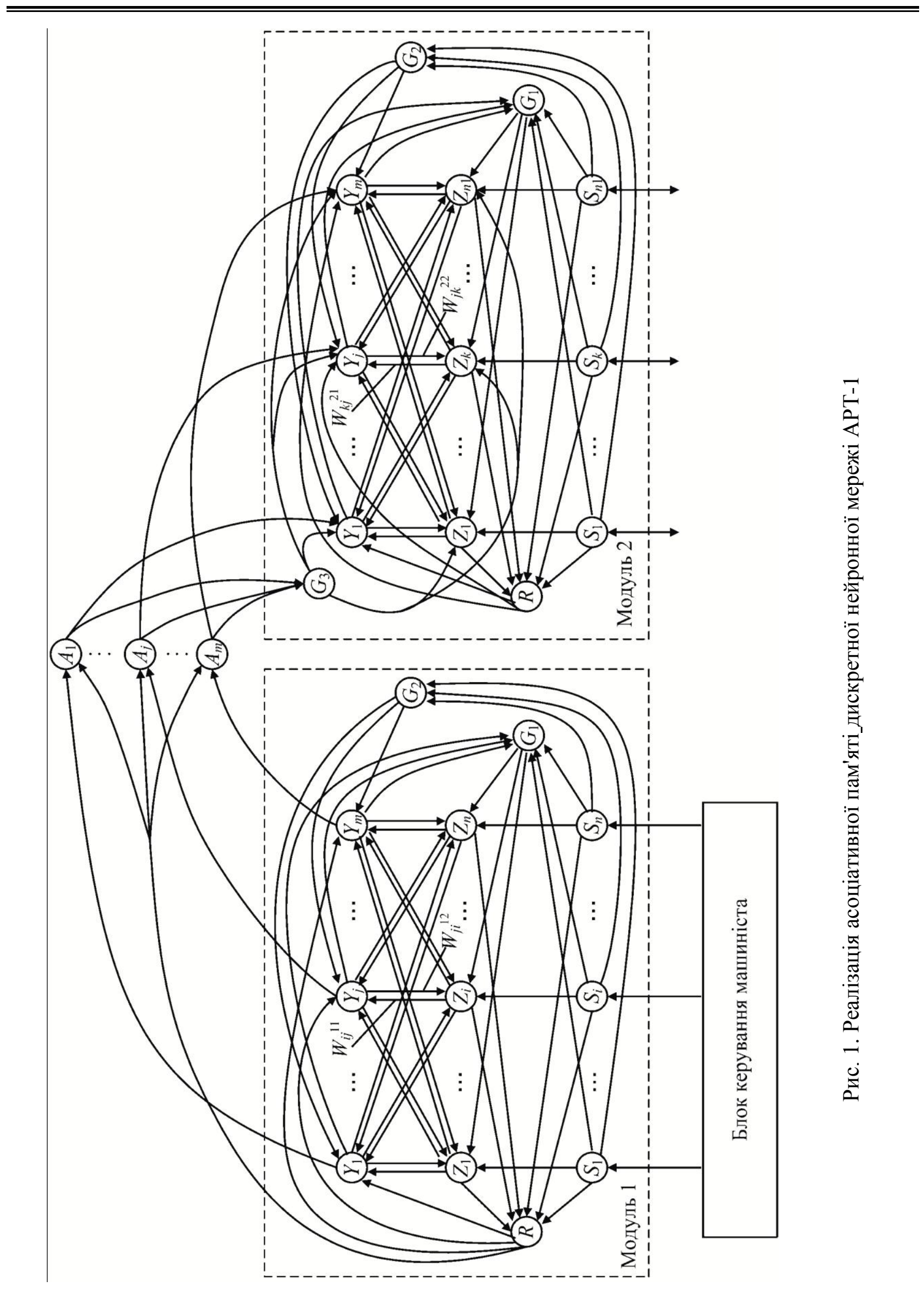

Збірник наукових праць УкрДАЗТ, 2013, вип. 136 
Алгоритм навчання модулів асоціативної пам'яті

Алгоритм навчання модулів асоціативної пам'яті відрізняється від класичних алгоритмів [4-6] такими особливостями:

1. Алгоритми навчання й розпізнавання розділені. У режимі розпізнавання не відбувається донавчання нейронної мережі.

2. При навчанні модулів використовується параметр подібності, що дорівнює одиниці.

3. Розподілені Ү-нейрони обох модулів не можуть у режимі навчання адаптувати свої ваги зв'язків.

В алгоритмах функціонування дискретних нейронних мереж АРТ-1 використовуються такі позначення:

$n, n 1$ - число компонент у вхідних векторах відповідно до модулів 1 і 2 асоціативної пам'яті;

$m$ - число розпізнавальних елементів у розпізнавальних шарах модулів 1 і 2;

$S^{1 k}, S^{1 l}$ - відповідно $n$ і $n$ l-вимірні вхідні вектори модулів 1 і 2 асоціативної пам'яті; $k=\overline{1,}_{1}, l=\overline{1, q}_{2}$; $q_{1}, q_{2}$ - число вхідних навчальних векторів відповідно до модулів 1 і 2;

$W_{i j}^{11}, \quad W_{k j}^{21} \quad-$ ваги зв'язків від інтерфейсних нейронів $Z_{i}(i=\overline{1, n})$, $Z_{k}(k=\overline{1, n 1})$ модулів 1 і 2 відповідно до елементів $Y_{j}(j=\overline{1, m})$ цих модулів;

$W_{j i}^{12}, \quad W_{j k}^{22}-$ ваги зв'язків від розпізнавальних нейронів $Y_{j}(j=\overline{1, m})$ модулів 1 і 2 відповідно до інтерфейсних елементів $Z_{i}(i=\overline{1, n})$ і $Z_{k}(k=\overline{1, n 1})$;

$p_{1}, \quad p_{2}-$ параметри подібності відповідно до модулів 1 і 2.

Алгоритм навчання модуля 1 асоціативної пам'яті

Крок 1. Ініціалізуються ваги зв'язків модуля $1 W_{i j}^{11}, W_{j i}^{21}(i=\overline{1, n}, j=\overline{1, m})$, задається параметр подібності $p_{1}=1$; задається безліч навчальних вхідних векторів $\left\{S^{11}, S^{12}, \ldots, S^{1 q_{1}}\right\}$.

Структура навчальних вхідних векторів можлива така:

\begin{tabular}{|c|c|c|c|c|}
\hline $\begin{array}{c}\text { Код лінії } \\
\text { метрополітену }\end{array}$ & Код станції & $\begin{array}{c}\text { Код напрямку } \\
\text { руху }\end{array}$ & $\begin{array}{c}\text { Код часу руху по } \\
\text { перегону }\end{array}$ & $\begin{array}{c}\text { Код } \\
\text { завантаженості } \\
\text { состава }\end{array}$ \\
\hline
\end{tabular}

Для Харківського метрополітену під код лінії можна виділити не більш двохтрьох розрядів, під код станції - 4 розряди, напрямок руху - один розряд, під код часу руху - 3-5 розрядів, під код завантаження состава - 2 розряди. Якщо для навчання першого модуля асоціативної пам'яті використовувати дані по "Салтівській" лінії метрополітену, то можна одержати навчальні вектори, частина 3 яких наведена в табл. 1.

Якщо задатися чотирма видами завантаження состава (порожній, завантажений на $25 \%$, завантажений на $50 \%$ і завантажений на $100 \%$ ), трьома часами руху состава (уповільнене, номінальне, прискорене) i двома можливими напрямками руху, то для "Салтівської" лінії метрополітену необхідно мати не менш $24\left(q_{1}=24\right)$ навчальних векторів, кожний з яких має 13 компонент, тобто $n=13$. Число розпізнавальних нейронів має бути не менше 24, тобто $m>=24$, візьмемо $m=24$.

Ваги зв'язків $W_{i j}^{11} \quad(i=\overline{1, n}, j=\overline{1, m})$ визначаються числом $n$ [4-6]:

$$
W_{i j}^{11}=\frac{1}{1+n}=\frac{1}{1+13}=0,071 .
$$


Таблиця 1

\begin{tabular}{|c|c|c|c|c|c|c|}
\hline $\begin{array}{c}\text { № } \\
\text { з/п }\end{array}$ & $\begin{array}{c}\text { Код } \\
\text { лінії }\end{array}$ & $\begin{array}{c}\text { Код } \\
\text { станції }\end{array}$ & $\begin{array}{c}\text { Код } \\
\text { напрямку } \\
\text { руху }\end{array}$ & $\begin{array}{c}\text { Код } \\
\text { часу } \\
\text { руху }\end{array}$ & $\begin{array}{c}\text { Код завантаження } \\
\text { состава }\end{array}$ & $\begin{array}{c}\text { Позначення } \\
\text { навчального } \\
\text { вектора }\end{array}$ \\
\hline 1 & 011 & 0001 & 1 & 001 & 01 & $S^{11}$ \\
\hline 2 & 011 & 0010 & 1 & 001 & 01 & $S^{12}$ \\
\hline 3 & 011 & 0011 & 1 & 001 & 01 & $S^{14}$ \\
\hline 4 & 011 & 0100 & 1 & 001 & 01 & $S^{15}$ \\
\hline 5 & 011 & 0101 & 1 & 001 & 01 & $S^{16}$ \\
\hline 6 & 011 & 0110 & 1 & 001 & 01 & $S^{17}$ \\
\hline 7 & 011 & 0111 & 1 (у тунель) & 001 & 01 & $S^{19}$ \\
\hline 8 & 011 & 0111 & 1 & 001 & 10 & $S^{1,10}$ \\
\hline 9 & 011 & 0110 & 1 & 001 & 10 & $S^{1,11}$ \\
\hline 10 & 011 & 0101 & 1 & 001 & 10 & $S^{1,12}$ \\
\hline 11 & 011 & 0100 & 1 & 001 & 10 & $S^{1,13}$ \\
\hline 12 & 011 & 0011 & 1 & 001 & 10 & $S^{1,14}$ \\
\hline 13 & 011 & 0010 & 1 & 001 & 10 & $\ldots$ \\
\hline 14 & 011 & 0001 & 1 (у тупик) & 001 & 10 & $\ldots$ \\
\hline$\ldots$ & $\ldots$ & $\ldots$ & $\ldots$ & $\ldots$ & & \\
\hline
\end{tabular}

Крок 2. Поки не виконуються умови припинення роботи алгоритму навчання першого модуля, для кожного навчального вектора $\quad\left\{S^{11}, S^{12}, \ldots, S^{1,23}, S^{1,24}\right\}$,

$$
U_{\text {вых }_{i}}=U_{\text {выхZ }_{i}}=U_{\text {вых } Y_{j}}=U_{\text {выхR }}=U_{\text {выхG } G_{1}}=U_{\text {вых } G_{2}}=0 .
$$

Навчальним тринадцятирозрядним бінарним вектором

$$
\begin{aligned}
& S^{11}=(0110001100101)= \\
& =\left(S_{1}^{11}, S_{2}^{11}, \ldots, S_{n}^{11}\right)
\end{aligned}
$$

визначаються вхідні й вихідні сигнали $\mathrm{S}$ елементів вхідного шару

$$
U_{\text {вых }_{i}}=U_{\mathrm{BxS}_{i}}=S_{i}^{11}, \quad i=\overline{1, n}, n=13 .
$$

виконується циклічна обробка інформації за допомогою кроків 3-11 алгоритму.

Крок 3. Задається нульова активація всіх нейронів першого модуля асоціативної пам'яті:

За допомогою розв'язувального нейрона $R$ визначається норма вхідного вектора:

$$
\left\|S^{11}\right\|=\left\|U_{\text {выхS }}\right\|=\sum_{i=1}^{n} S_{i}^{11}=6 .
$$

Крок 4. Визначаються вхідні й вихідні сигнали керуючих нейронів $G_{1}, G_{2}$ i нейронів інтерфейсного шару: 


$$
\begin{aligned}
& U_{\mathrm{Bх} G_{1}}=U_{\mathrm{BхG}_{2}}>0 ; \\
& U_{\text {вых } G_{1}}=U_{\text {вых } G_{2}}=1 ; \\
& U_{\mathrm{BхZ}_{i}}=U_{\mathrm{Bых}_{i}} \quad i=\overline{1, n} ; \\
& U_{\text {вых }_{i}}=U_{\mathrm{Bх} Z_{i}} \cdot U_{\text {вых } G_{1}} \quad i=\overline{1, n} .
\end{aligned}
$$

Крок 5. Для всіх незагальмованих розпізнавальних нейронів розраховуються їхні вхідні й вихідні сигнали:

$$
\begin{gathered}
U_{\mathrm{Bx} Y_{j}}=\sum_{i=1}^{n} U_{\mathrm{Bbx} Z_{i}} \cdot W_{i j}^{1} ; \quad U_{\mathrm{Bx} Y_{1}}=U_{\mathrm{Bx} Y_{2}}=\ldots=U_{\mathrm{Bx} Y_{24}}=0,923 ; \\
U_{\mathrm{Bыx} Y_{j}}=U_{\mathrm{Bx} Y_{j}} \cdot U_{\mathrm{Bых} G_{2}} .
\end{gathered}
$$

Крок 6. Починається пошук розпізнавального Ү-нейрона, ваговий коефіцієнт якого відповідає вхідному зображенню із заданим параметром подібності $p_{1}$ першого модуля. Пошук виконується циклічно за допомогою кроків 7-9 алгоритму.

Крок 7. У розпізнавальному шарі елементів визначається нейрон $\mathrm{Y}_{\mathrm{J}}$, вихідний сигнал якого підпорядковується умові

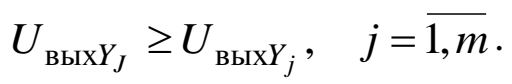

Якщо цю умову задовольняє два або більше Ү-нейронів, то вибирається нейрон 3 найменшим номером. $\mathrm{Y}$ розглянутому прикладі, коли вектор $S^{11}$ подається першим, зазначену умову задовольняють усі Ү-нейрони, тому $J=1$. Якщо виявляється, що $U_{\text {вых } Y_{J}}=-1, \quad$ то пред'явлене зображення не можна класифікувати, оскільки за параметром подібності воно не відповідає жодному із зображень, що зберігаються у вагах зв'язків Ү-елементів. Тому всі нейрони Ү-шару загальмовані.

Крок 8. Визначаються сигнали на виходах елементів інтерфейсного шару за правилом "два із трьох":

$$
U_{\text {выхZ }_{i}}=U_{\text {вых }_{i}} W_{J i}^{2}, \quad i=\overline{1, n},
$$

і розраховується норма вектора $U_{\text {выхZ }}$ :

$$
\left\|U_{\text {выхZ }}\right\|=\sum_{i=1}^{n} U_{\text {выхZ }_{i}} \cdot
$$

$$
\begin{aligned}
& \text { У розглянутому прикладі } \\
& U_{\text {выхZ }_{i}}=U_{\text {вых }_{i}}, \quad i=\overline{1, n} \text {, тому } \\
& \left\|U_{\text {выхZ }}\right\|=\left\|U_{\text {выхS }}\right\|=6 \text {. }
\end{aligned}
$$

Крок 9. За допомогою параметра подібності визначається можливість навчання нейрона $Y_{J}$ :

$$
\text { якщо }\left\|U_{\text {выхZ }}\right\| /\left\|U_{\text {выхS }}\right\| \geq p_{1}, \quad \text { то }
$$

навчання можливе, і воно здійснюється на наступному кроці алгоритму;

$$
\text { якщо }\left\|U_{\text {выхZ }}\right\| /\left\|U_{\text {выхS }}\right\|<p_{1}, \quad \text { то }
$$

зображення за параметром подібності не належать до одного класу, тому нейрон $Y_{J}$ має бути загальмований $\left(U_{\text {выхJ }}=-1\right)$, а алгоритм повинен продовжити свою роботу із кроку 7.

$$
\text { У розглянутому прикладі }
$$
$\left\|U_{\text {выхZ }}\right\| /\left\|U_{\text {выхS }}\right\|=1$, тому навчання ваг зв'язків мережі можливе, i воно здійснюється на 10-му кроці роботи алгоритму.

Крок 10. Навчання або адаптація вагових коефіцієнтів зв'язків нейрона $Y J$ здійснюється за допомогою відомих співвідношень [4-6]: 


$$
W_{i J}^{1}=\frac{2 U_{\text {выхZ }_{i}}}{1+\left\|U_{\text {выхZ }}\right\|}, \quad W_{J i}^{2}=U_{\text {выхZ }}, \quad i=\overline{1, n} .
$$

У розглянутому прикладі маємо:

$$
\begin{aligned}
& W_{11}^{1}=W_{41}^{1}=W_{51}^{1}=W_{61}^{1}=W_{91}^{1}=W_{10,1}^{1}=W_{12,1}^{1}=0 ; \\
& W_{21}^{1}=W_{31}^{1}=W_{71}^{1}=W_{81}^{1}=W_{11,1}^{1}=W_{13,1}^{1}=\frac{2 \cdot 1}{1+6}=0,286 ; \\
& W_{11}^{2}=W_{14}^{2}=W_{15}^{2}=W_{16}^{2}=W_{19}^{2}=W_{1,10}^{2}=W_{1,12}^{2}=0 ; \\
& W_{12}^{2}=W_{13}^{2}=W_{17}^{2}=W_{18}^{2}=W_{1,10}^{2}=W_{1,12}^{2}=1 .
\end{aligned}
$$

У розглянутому прикладі матриця $W^{1}$ ваг зв'язків від Z-нейронів до Ү-нейронам буде мати такий вигляд. Розміри матриці$13 \times 24$.

Крок 11. Перевіряються умови зупинника процесу навчання нейронної мережі. Такими умовами можуть бути: сталість усіх ваг зв'язків нейронної мережі протягом епохи; виконання заданого числа епох навчання нейронної мережі $\mathrm{i}$ т.д. Якщо умови зупинки виконуються, то перехід до останнього кроку алгоритму. А якщо ні, то - перехід до кроку 2 алгоритму.

$$
\text { У розглянутому прикладі }
$$
здійснюється перехід до кроку 2 алгоритму.

$$
W^{1}=\left|\begin{array}{ccccc}
0 & 0,071 & 0,071 & \ldots & 0,071 \\
0,286 & 0,071 & 0,071 & \ldots & 0,071 \\
0,286 & 0,071 & 0,071 & \ldots & 0,071 \\
0 & 0,071 & 0,071 & \ldots & 0,071 \\
0 & 0,071 & 0,071 & \ldots & 0,071 \\
0 & 0,071 & 0,071 & \ldots & 0,071 \\
0,286 & 0,071 & 0,071 & \ldots & 0,071 \\
0,286 & 0,071 & 0,071 & \ldots & 0,071 \\
0 & 0,071 & 0,071 & \ldots & 0,071 \\
0 & 0,071 & 0,071 & \ldots & 0,071 \\
0,286 & 0,071 & 0,071 & \ldots & 0,071 \\
0 & 0,071 & 0,071 & \ldots & 0,071 \\
0,286 & 0,071 & 0,071 & \ldots & 0,071
\end{array}\right|
$$


Крок 2. На вхід нейронної мережі подається другий навчальний вектор $S^{12}=(0110010100101)$.

Крок 3. Задається нульова активність усіх нейронів першого модуля асоціативної пам'яті. Навчальним вектором $S^{12}$ визначаються вхідні й вихідні сигнали Sелементів вхідного шару:

$$
\begin{aligned}
& U_{\text {вых } S_{i}}=U_{\text {вх } S_{i}}=0, \quad i=1,4,5,7,9,10,12 \text {; } \\
& U_{\text {вых }_{i}}=U_{\text {вх } S_{i}}=1, \quad i=2,3,6,8,11,13 .
\end{aligned}
$$

Визначається норма вхідного вектора:

$$
\left\|S^{12}\right\|=\left\|U_{\text {выхS }}\right\|=\sum_{i=1}^{13} S_{i}^{12}=6 .
$$

Крок 4. За співвідношеннями (5.13) визначаються вхідні й вихідні сигнали керуючих нейронів $G_{1}, G_{2}$ i нейронів інтерфейсного шару. При вхідному векторі $S^{12}$ маємо:

$$
\begin{gathered}
U_{\text {выхZ }_{i}}=0, \quad i=1,4,5,7,9,10,12 ; \\
U_{\text {вых }_{i}}=1, \quad i=2,3,6,8,11,13 .
\end{gathered}
$$

Крок 5. Розраховуються вхідні й вихідні сигнали всіх Ү-нейронів:

$$
\begin{aligned}
& U_{\mathrm{Bх} Y_{1}}=\sum_{i=1}^{13} U_{\mathrm{BыхZ}_{i}} \cdot W_{i 1}=1 \cdot 0,286 \cdot 6=1,716 ; \\
& U_{\mathrm{Bх} Y_{2}}=\sum_{i=1}^{13} U_{\mathrm{BыхZ}_{i}} \cdot W_{i 2}=1 \cdot 0,071 \cdot 13=0,923 ; \\
& U_{\mathrm{Bх} Y_{2}}=U_{\mathrm{Bх} Y_{3}}=\ldots=U_{\mathrm{Bх} Y_{24}}=0,923 ; \\
& U_{\text {вых } Y_{1}}=1,716 ; \\
& U_{\text {вых } Y_{2}}=U_{\text {вых } Y_{3}}=\ldots=U_{\text {вых } Y_{24}}=0,923 .
\end{aligned}
$$

Крок 6-9. На першому етапі пошуку нейрона-переможця в Y-щарі маємо $J=1$, однак визначення параметра подібності

$$
\left\|U_{\text {выхZ }}\left(S^{12}\right)\right\| /\left\|U_{\text {выхS }}\left(S^{12}\right)\right\|=5 / 6=0.833<p_{1}=1
$$


показує, що вектор, що зберігається у вагах зв'язків нейрона $Y_{1}$, недостатньо схожий на вхідний вектор $S^{12}$. Тому нейрон $Y_{1}$ має бути загальмований і початий новий цикл пошуку нейрона-переможця в шарі розпізнавальних нейронів. Цей цикл починається кроком 6 і закінчується кроком 9. При цьому як нейронпереможець виділяється нейрон $Y_{2}$.

Крок 10. Адаптуються вагові коефіцієнти зв'язків нейрона $Y_{2}$ за допомогою співвідношення:

$$
W_{i 2}^{1}=\frac{2 U_{\text {вых } Z_{i}}}{1+\left\|U_{\text {вых } Z_{i}}\right\|} ; \quad W_{2 i}^{2}=U_{\text {вых } Z_{i}} ; \quad i=\overline{1, n} .
$$

Для розглянутого нейрона $Y_{2}$ маємо:

$$
\begin{aligned}
& W_{12}^{1}=W_{42}^{1}=W_{52}^{1}=W_{72}^{1}=W_{92}^{1}=W_{10,2}^{1}=W_{12,2}^{1}=0 \\
& W_{22}^{1}=W_{32}^{1}=W_{61}^{1}=W_{82}^{1}=W_{11,2}^{1}=W_{13,2}^{1}=\frac{2}{1+6}=0,286 \\
& W_{21}^{2}=W_{24}^{2}=W_{25}^{2}=W_{27}^{2}=W_{29}^{2}=W_{2,10}^{2}=W_{2,12}^{2}=0 ; \\
& W_{22}^{2}=W_{23}^{2}=W_{26}^{2}=W_{28}^{2}=W_{2,11}^{2}=W_{2,13}^{2}=1
\end{aligned}
$$

Матриця $W^{1}$ ваг зв'язків від Z-нейронів до Y-нейронам буде мати вигляд:

$$
W^{1}=\left|\begin{array}{ccccc}
0 & 0 & 0,071 & \ldots & 0,071 \\
0,286 & 0,286 & 0,071 & \ldots & 0,071 \\
0,286 & 0,286 & 0,071 & \ldots & 0,071 \\
0 & 0 & 0,071 & \ldots & 0,071 \\
0 & 0 & 0,071 & \ldots & 0,071 \\
0 & 0,286 & 0,071 & \ldots & 0,071 \\
0,286 & 0 & 0,071 & \ldots & 0,071 \\
0,286 & 0,286 & 0,071 & \ldots & 0,071 \\
0 & 0 & 0,071 & \ldots & 0,071 \\
0 & 0 & 0,071 & \ldots & 0,071 \\
0,286 & 0,286 & 0,071 & \ldots & 0,071 \\
0 & 0 & 0,071 & \ldots & 0,071 \\
0,286 & 0,286 & 0,071 & \ldots & 0,071
\end{array}\right|
$$


Крок 11. Перевіряються умови зупинника. Оскільки використані не всі навчальні вхідні вектори, то здійснюється перехід до кроку 2 алгоритму, де починається навчання вектором $S^{13}$. Оскільки при навчанні нейронної мережі використовується параметр подібності, що дорівнює одиниці, то перехід до останнього кроку алгоритму може бути здійснений після навчання мережі вхідним навчальним вектором $S^{1,24}$.

Алгоритм навчання модуля 2 асоціативної пам'яті

Кожному коду, що надходить на вхід модуля 1 асоціативної пам'яті, має відповідати унікальна залежність $v=v(S)$, що описує рух состава по заданому перегону при заданому завантаженні й часі руху состава та зберігається в модулі 2 асоціативної пам'яті. На рис. 2. наведений приклад навчального зображення для модуля 2. Незважаючи на те що для навчання нейронної мережі має використовуватися послідовність зображень, кожне 3 яких містить $n 1=120 \times 100=12000$ пікселів, навчання другого модуля нейронної мережі виконується аналогічно навчанню першого модуля асоціативної пам'яті. При цьому навчальні зображення 3 функціями $v=v(S)$ необхідно подавати таким чином, що розпізнавальні нейрони модуля $2 \mathrm{Y}_{1}, \mathrm{Y}_{2}$, ..., $\mathrm{Y}_{\mathrm{m}}$ зберігали у своїх вагах зв'язків функції $v(S), \quad$ відповідні до кодів навчальних $S^{11}, S^{12}, \ldots, S^{1,24}$ векторів, що зберігаються в пам'яті нейронів $\mathrm{Y}_{1}, \mathrm{Y}_{2}, \ldots$, $\mathrm{Y}_{\mathrm{m}}$ першого модуля асоціативної пам'яті.

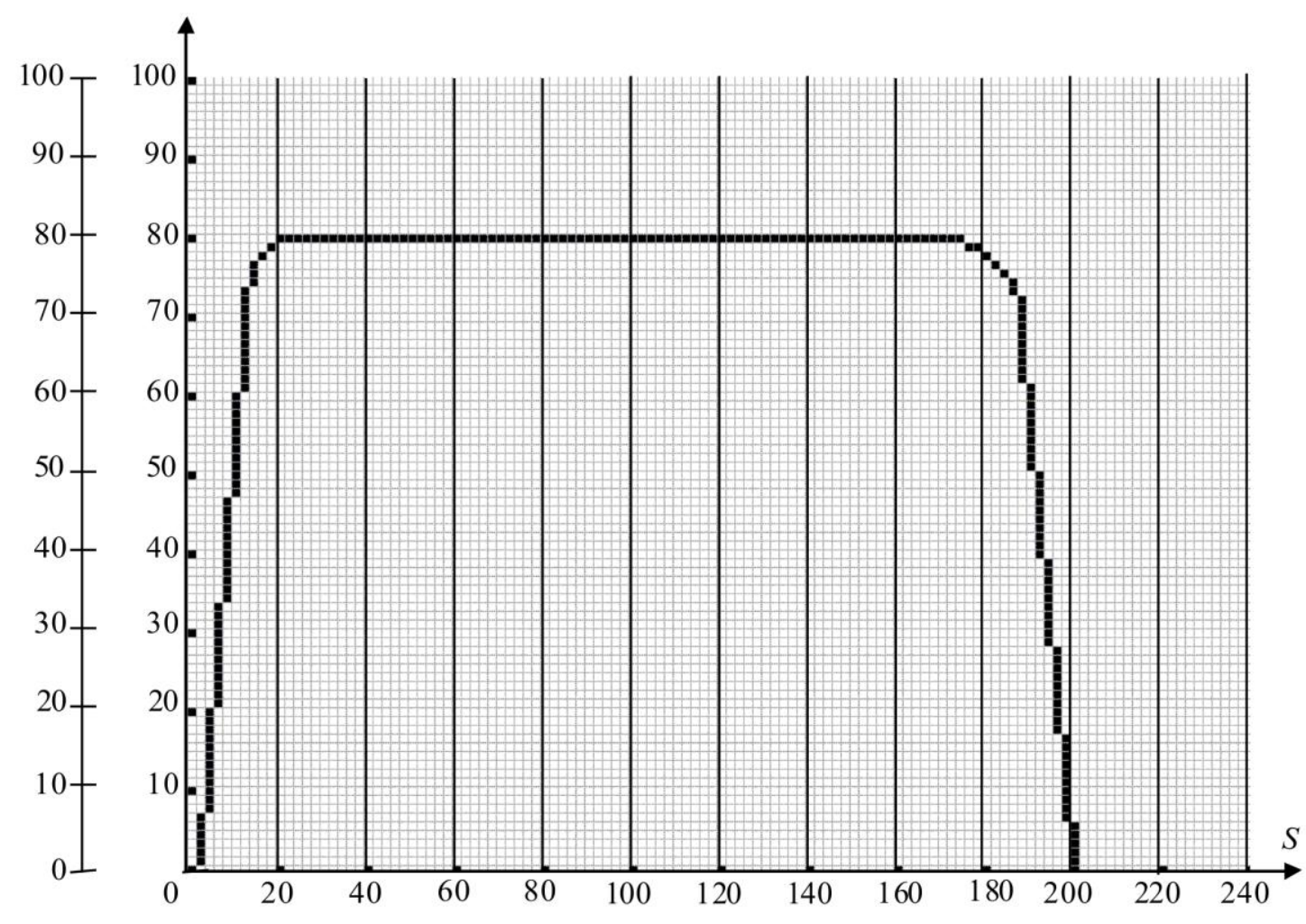

Рис. 2. Приклад навчального зображення для модуля 2 
4. Алгоритм функціонування асоціативної пам'яті за підтримки рішень машиніста

Крок 1. При відправленні зі станції машиніст за допомогою блока керування задає нульову активацію всіх нейронів першого модуля й керуючий вектор $S^{y}=\left(S_{1}^{y}, S_{2}^{y}, \ldots, S_{n}^{y}\right)$, що надходить на входи S-елементів першого модуля.

Крок 2. Визначаються вхідні й вихідні сигнали елементів вхідного шару:

$$
\begin{gathered}
U_{\mathrm{Bх} S_{i}}=S_{i}^{y}, \quad i=\overline{1, n}, \quad n=13 ; \\
U_{\mathrm{Bых}_{i}}=U_{\mathrm{BX}_{i}} S_{i}, \quad i=\overline{1, n}, \quad n=13 .
\end{gathered}
$$

Визначається норма вхідного вектора

$$
\left\|S^{y}\right\|=\left\|U_{\text {вых }_{i}}\right\|=\sum_{i=1}^{n} S_{i}^{y}=\sum_{i=1}^{n} U_{\text {вых }_{i}}
$$

Крок 3. Визначаються вхідні й вихідні сигнали керуючих нейронів $G_{1}, G_{2}$ i Z-нейронів:

$$
\begin{aligned}
& U_{\mathrm{BX} G_{1}}=U_{\mathrm{BX} G_{2}}>0 \text {; } \\
& U_{\text {вых } G_{1}}=U_{{\text {вых } G_{2}}}=1 \text {; } \\
& U_{\mathrm{Bx}_{i}}=U_{\mathrm{Bdx}_{i}}, \quad i=\overline{1, n} ; \\
& U_{\text {вых }_{i}}=U_{\text {вх } Z_{i}} \cdot U_{\text {вых } G_{1}}, \quad i=\overline{1, n} .
\end{aligned}
$$

Крок 4. Розраховуються вхідні й вихідні сигнали розпізнавальних нейронів:

$$
\begin{gathered}
U_{\mathrm{Bx} Y_{j}}=\sum_{i=1}^{n} U_{\text {вых }_{i}} \cdot W_{i j}^{1} ; \\
U_{\mathrm{Bыx}_{j}}=U_{\mathrm{Bx} Y_{j}} \cdot U_{\mathrm{Bых} G_{2}} \cdot
\end{gathered}
$$

Крок 5. У розпізнавальному шарі нейронів визначається нейрон $\mathrm{Y}_{\mathrm{J}}$, вихідний сигнал якого підпорядковується умові

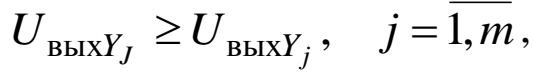

а вміст пам'яті нейрона за параметром подібності відповідає вхідному вектору $S^{y}$. У цьому випадку на виході нейронів $Y_{J}$ і $R$ з'являються одиничні вихідні сигнали:

$$
U_{\text {вых } Y_{J}}=1 ; \quad U_{\text {выхR }}=1 .
$$

Крок 6. Одиничні вихідні сигнали $U_{\text {выхY }}$ й $U_{\text {выхR }}$ надходять на вхід нейрона $A_{J}$, який визначає свій вихідний сигнал за допомогою співвідношення

$$
U_{\text {вых } A_{J}}= \begin{cases}1, & \text { если } U_{\text {выхR }}+U_{\text {вых } Y_{J}}=2, \\ 0, & \text { если } U_{\text {выхR }}+U_{\text {вых } Y_{J}}<2 .\end{cases}
$$

Крок 7. Одиничний вихідний сигнал $U_{\text {вых }}$ переводить в активний стан керуючий нейрон $G_{3} \quad\left(U_{\text {выхG }}=1\right)$ і надходить на вхід нейрона $Y_{J}$ модуля 2. Нейрон $Y_{J}$ переходить в активний стан $\left(U_{\text {вых }}=1\right)$, оскільки на його входи надходять одиничні сигнали із двох джерел: 3 виходу нейронів $A_{J}$ i $G_{3}$.

Крок 8. Сигнали $U_{\text {выхG }_{3}}=1$, $U_{\text {вых } Y_{J}}=1$ надходять на входи всіх Zнейронів, вихідні сигнали яких визначаються співвідношеннями:

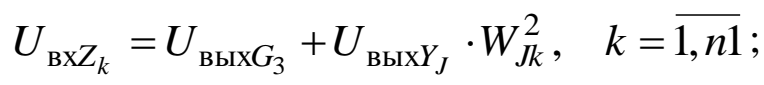

$$
U_{\text {вых } Z_{k}}= \begin{cases}1, & \text { если } U_{\text {вх } Z_{k}}=2, \\ 0, & \text { если } U_{\text {вх } Z_{k}}<2,\end{cases}
$$

де $W_{J k}^{2}$ - вага зв'язку від нейрона $Y J$ до нейрона $Z k, k=\overline{1, n 1}$. Вага зв'язку $W_{J k}^{2}$ $(k=\overline{1, n 1})$ може дорівнювати тільки 0 або 1. 
Крок 9. Розраховуються вхідні й вихідні сигнали нейронів S-шару:

$$
\begin{aligned}
& U_{\mathrm{BX}_{k}}=U_{\mathrm{Bbx}_{k}}, \quad k=\overline{1, n 1} ; \\
& U_{\mathrm{Bbx}_{k}}=U_{\mathrm{Bx} S_{k}}, \quad k=\overline{1, n 1} .
\end{aligned}
$$

Крок 10. Вихідні сигнали нейронів Sшару подаються на вхід обладнання візуалізації для відображення заданої траєкторії руху состава по заданому перегону.

Крок 11. Зупинка.

Висновок. На основі нейронних мереж адаптивної резонансної теорії розроблена асоціативна пам'ять для зберігання законів керування рухом составів метрополітену, що дозволяє мінімізувати енергетичні витрати та забезпечує графік руху й комфортні умови перевезення пасажирів. Реалізація системи не вимагає внесення змін у силову схему електропривода вагона й у iii систему керування. Для організації роботи нейронної мережі досить мати програмноапаратне обладнання, до складу якого входить бортовий комп'ютер з відповідним програмним забезпеченням i апаратний блок, за допомогою якого фіксується проходження поїзда через контрольні пункти, розташовані на певній відстані від станції, 3 наступним визначенням у бортовому комп'ютері всіх параметрів руху поїзда (швидкість, прискорення, координата) й виведенням на дисплей інформації у вигляді реальної та рекомендованої траєкторії руху поїзда. Розроблений метод оптимізації руху поїзда метрополітену має універсальність і може бути розповсюджений до використання на усіх видах рухомого складу.

\section{Список літератури}

1. Астрахан, В.И. Системы автоведения для управления поездами метрополитена [Текст] / В.И. Астрахан, Ю.А. Барышев. - М.: Транспорт, 1989. - 88 с.

2. Блиндюк, В.С. Аналіз основних етапів розвитку систем автоматичного керування рухом на залізничному транспорті та в метрополітенах [Текст] / В.С. Блиндюк // Зб. наук. праць. - Харків: УкрДАЗТ, 2011. - Вип. 126. - С. 86-90.

3. Блиндюк, В.С. Керування електропоїздами метрополітену на основі нейронних мереж адаптивної резонансної теорії. Частина 1. Побудова асоціативної пам'яті на основі нейронних мереж адаптивної резонансної теорії [Текст] / В.С. Блиндюк // Зб. наук. праць. Харків: УкрДАЗТ, 2013. - Вип. 135. - С. 20-25.

4. Дмитриенко, В.Д. Основы теории нейронных сетей / В.Д. Дмитриенко, Н.И. Корсунов // Белгород: БИИММАП, 2001. - 159 с.

5. Моделирование и оптимизация систем управления и контроля локомотивов / В.И. Носков, В.Д. Дмитриенко, Н.И. Заполовский, С.Ю. Леонов. - Харьков: ХФИ "Транспорт Украины", 2003. - 248 с.

6. Fausett I. Fundamentals of Neural Networks. Architectures, Algorithms, and Application. New Jersey: Prentice Hall International, Inc., 1994. - 461 p.

Ключові слова: електропоїзд, нейронна мережа, асоціативна пам'ять, модуль, перегін, шар нейронів, траєкторія руху.

\section{Анотаціi}

На основі нейронних мереж адаптивної резонансної теорії розроблено асоціативну пам'ять для зберігання законів керування рухом составів метрополітену, яка не вимагає 
внесення змін у силову схему електропривода вагона й у їі систему керування. Розроблений метод оптимізації руху поїзда метрополітену має універсальність i може бути розповсюджений до використання на всіх видах рухомого складу.

На основе нейронных сетей адаптивной резонансной теории разработанная ассоциативная память для хранения законов управления движением составов метрополитена, которая не требует внесения изменений в силовую схему электропривода вагона и в ее систему управления. Разработанный метод оптимизации движения поезда метрополитена имеет универсальность и может быть использован на всех видах подвижного состава.

On the basis of neural networks of the adaptive resonant theory the developed associative memory for storage of control laws by motion of railroad trains of underground which does not demand modification of the power scheme of the electric drive of the coach and of its control system. The developed method of optimisation of train movements of underground has universality and can be spread to usage on all kinds of railway vehicles. 